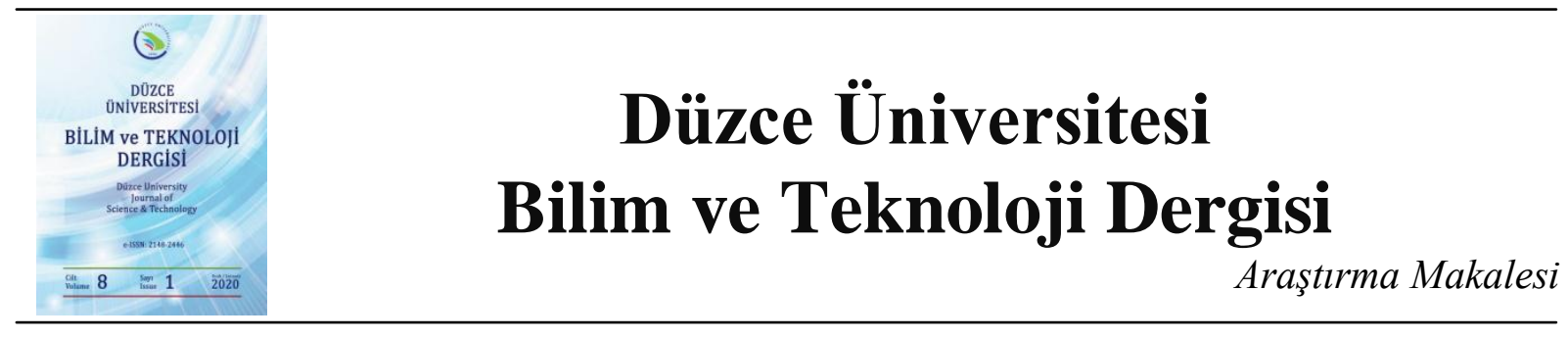

\title{
Kestane Baltalıklarında Aralamaların Büyümeye Kısa Süreli Etkileri
}

\author{
(iD) Ali Kemal ÖZBAYRAM ${ }^{\mathrm{a}, *}$, (iD Burak SEÇGiN ${ }^{\mathrm{b}}$ \\ ${ }^{a}$ Orman Mühendisliği Bölümü, Orman Fakültesi, Düzce Üniversitesi, Düzce, TÜRKIYE \\ ${ }^{b}$ Orman Mühendisliği, Fen Bilimleri Enstitüsü, Düzce Üniversitesi, Düzce, TÜRKIYE \\ * Sorumlu yazarin e-posta adresi: alikemalozbayram@duzce.edu.tr \\ DOI: $10.29130 /$ dubited.621613
}

\begin{abstract}
ÖZET
Türkiye'nin önemli orman ağaçlarından biri olan Anadolu kestanesi (Castanea sativaMill.) geniş alanlarda saf ve karışık meşcereler kurmaktadır. Kestane biyolojisine aykırı uygulamalar ve çeşitli hastalıklar nedeniyle koru kestane ormanlarının vasfi bozulmuş, birçok yerde baltalık vasıflı işletilmesi silvikültürel seçenek haline gelmiştir. Aralama, ormanların işletilmesinde kullanılan en önemli silvikültürel müdahalelerden biridir. $\mathrm{Bu}$ çalışmanın amacı Gölcük (Kocaeli) yöresi 15 yaşındaki kestane baltalıklarında aralama şiddetinin çap, göğüs yüzeyi ve hacim ile bunların artımlarına bir yıllık etkilerini değerlendirmektir. Aralama denemesi rastlantı blokları deneme desenine göre üç tekrarlı kurulmuş ve dört farklı aralama şiddeti uygulanmıştır. Aralama öncesi meşcere ağaç sayısı, orta çapı, göğüs yüzeyi ve hacmi sırasıyla 4936 adet, $8.73 \mathrm{~cm}, 30.71 \mathrm{~m}^{2}$ ha ${ }^{-1}$ ve $163.68 \mathrm{~m}^{3}$ $\mathrm{ha}^{-1}$ 'd. Aralama ile göğüs yüzeyinin \% 0 (kontrol), \% 18'si (mutedil), \% 34'ü (şiddetli) ve \% 49'u (çok şiddetli) meşcereden çıkartılmıştır. Aralamanın bir yıllık sonuçlarına göre; aralama şiddeti arttıkça çap artımı artmakta, buna bağlı olarak aralanan parseller kontrol kadar göğüs yüzeyi ve hacim artımı yapmışlardır. Çok şiddetli aralanan meşceredeki çap artımı kontrolün iki katı kadardır. Aralama şiddetine bağlı olarak başlangıç çap sınıfları arttıkça çap artımı da artmıştır. Aralamanın büyümeye etkisi bağlamında daha uzun süreli sonuçlara ihtiyaç duyulmakla birlikte, ulaşılan bir yıllık sonuçlara göre benzer özellikteki kestane baltalıklarında çok kuvvetli aralamalar önerilebilir.
\end{abstract}

Anahtar Kelimeler: Aralama, Baltalı, Castanea sativa, Büyüme, Artım

\section{Short-time Effects of Thinning on The Growth of Chestnut Coppice}

\begin{abstract}
Anatolian chestnut (Castanea sativa Mill.) is one of the most important hardwood forest tree in Turkey and it has mixed and pure stands in large areas. Due to the practices contrary to the biology of chestnut and various diseases, the chestnut high forests has been degraded and coppice system has become a silvicultural necessity in many places. Thinning is one of the most important silvicultural treatments used in the tending of forests. The aim of this study was to evaluate the effects of thinning intensity on diameter, basal area and volume, and also their increments of chestnut coppices in Gölcük (Kocaeli) district. The thinning experiment was established according to randomized block design with three replications and four different thinning intensities. Before thinning tree number, mean diameter, basal area and volume of the coppice stand were 4936 trees, $8.73 \mathrm{~cm}$, $30.71 \mathrm{~m}^{2} \mathrm{ha}^{-1}$ and $163.68 \mathrm{~m}^{3} \mathrm{ha}^{-1}$, respectively. The thinning intensities were removal of basal area as $0 \%$ (control), 18.2\% (moderate), 34\% (heavy) and 49\% (very heavy). According to the one year results; as the thinning intensity increased, the diameter increment increased, and as a result the basal area and volume in the thinned stands increased as much as the control. The diameter increment at the very heavy thinned plots was as twice the control. As the initial diameter classes and thinning intensity increased, the diameter increment also increased. According to the one year results, thinning intensity up to $40 \%$ can be suggested in similar chestnut coppices. However, the long term effects of the thinning treatments should be evaluated.
\end{abstract}

Keywords: Castanea sativa, Thinning, Coppice, Growth, Increment 


\section{GİRIS}

Ülkemizin önemli yapraklı ormanlar ağaçlarından birisi de Anadolu kestanesi (Castanea sativaMill.)'dir. Özellikle çok amaçlı kullanımlar için son derece önemli potansiyele sahip türlerden biridir. Bununla birlikte kestane ormanlarımızın uzun yıllar bütün dünyada olduğu gibi ülkemizde de biyotik ve abiyotik zararlılarla yok olma tehlikesiyle karşı karşıya kalmıştır.Biyolojisine aykırı uygulamalarla kestane ormanlarının vasfi bozulmuş, birçok yerde aşı vb. çalışmalarla niteliği değiştirilmeye çalışılmıştır [1].

Kestane değerli odunu ve geniş kullanım alanı (meyve, bal, vb.) ve ayrıca görselliği nedeniyle önemli bir türdür. Kestane meşcereleri uzun yıllar yoğun olarak kullanıldığından büyük baskı görmüştür. $\mathrm{Bu}$ baskı sonucunda kestane meşcereleri giderek azalmıştır [2]. Anadolu kestanesinin odunu, meyvesi ve çiçeği oldukça değerlidir. Sağlamlığı ve suya dayanıklılığı nedeniyle ahşap ev yapımı, pencere ve kap1 çerçevesi gibi birçok mobilya, tekne ve yat imalatında kullanılabilmektedir. Ayrıca meyvesinden, kestane balı, kestane şekeri ve marmelatı gibi birçok yönden faydalanılmaktadır.

Anadolu kestanesine mürekkep hastalığı (kök çürüklüğü), dal kanseri ve gal oluşumu gibi hastalıklar ciddi zararlar vermektedir [3]. Dal kanseri ve mürekkep hastalığına karşı henüz etkili bir önlem alınamamasından dolayı, kestanenin ölümüne olanak vermeden kısa idare süresiyle baltalık olarak işletmesi, pratik uygulamada en uygun silvikültürel yaklaşım/önlem olarak görülmektedir. $\mathrm{Bu}$ bağlamda Gölcük yöresindeki kestane meşcereleri hastalıklarla mücadele ve kısa idare süresinden yararlanmak için tıraşlama kesilerek baltalık olarak işletilmektedir. Bu işletme şekliyle Gölcükte'ki kestane baltalıklarından 4 yıl idare süresiyle kestane çubuğu (bambu yerine), 20 yıl idare süresiyle çit kazığı ve direk üretimi yapılmaktadır[4].

Koru vasıflı kestane ormanları için 50 yıl, baltalık kestane ormanları için 20-30 yıl idare süresi ile işletilmesi önerilmektedir[5]. Normal sıklıkta, 25 yaşında I bonitte $19 \mathrm{~m}^{3}$, III. bonitette14.0 $\mathrm{m}^{3}, \mathrm{~V}$. Bonitette9.1 $\mathrm{m}^{3}$ genel ortalama artıma ulaşmasıyla kestane hızlı gelişen tür yeteneğine sahiptir. Türkiye'de hızlı gelişen Dişbudak, Kızılağaç ve Kızılçam gibi türlerden daha hızlı büyümektedir[5].Kestanenin hasılatı, odun özellikleri, kimyası ve hastalıklarıyla mücadele hususunda birçok çalışma olmasına karşın [1, 2, 5-8], kestane baltalık ormanlarında aralamanın büyüme üzerine etkilerini konu alan çalışmaya rastlanmamıştır.

Meşcere yetiştirmede en önemli bakım tedbirlerinin aralama olduğu söylenebilir [3]. Meşcere özelliklerine göre zamanında ve düzenli şekilde yapılacak bakımlar kaliteli ve kalın çaplı odun ürünü üretimi için kullanılabilecek en önemli silvikültürel araçtır. Aşırı gövde sıklığı ve gövde ayrılmasından kaynaklanan artım kayıplarını en aza indirmek ve ormanların canlılığını ve çeşitliliği korumak için aralama müdahaleleri zorunludur [9-12]. Diğer yandan; yetişme ortamı, ağaç türü ve meşcere kuruluş özelliklerine bağlı olarak, farklı şiddetlerde uygulanacak aralamalar, meşcere kuruluşu ve gelişimi yanında ağaçların biçimi ve gelişimi ile meşcere sağlığı, toprak özellikleri ve meşcerenin gelecekteki gençleştirme koşulları üzerine büyük ölçüde etkili olduğu ifade edilmektedir [12].

Aralama meşcere sıklığını ve ona bağlı olarak rekabeti (1şık, su ve besin maddesi) düşürmek için yapılır. Bazı bireylerin uzaklaştırılmasıyla kalan bireylerin rekabet gücü artmış olur. Yüksek meşcere sıklıklarında birçok ağacın yaşama gücü azalır ve ara ve alt tabakaya iner, zamanla ölerek meşcereden ayrılır. Aralama bu ağaçları ölmeden değerlendirir ve toplam meşcere üretimini arttırır. Aralamalarla meşceredeki ağaç sayısının azaltılmasıyla birlikte kalan ağaçlar tepe ve kök gelişimi için daha fazla alan bulurlar, çap artımı hızlanır ve ağaçlar kullanılabilir bir çapa daha kısa sürede ulaşır [13-15].

Araştırmanın yapıldığı Gölcük yöresinde yaklaşık 4500 hektar saf ve karışık kestane ormanı bulunmaktadır [4]. Bu çalışmanın amacı Gölcük yöresindeki kestane baltalık ormanlarında aralama şiddetinin çap, gögüs yüzeyi ve hacim gelişimi üzerine bir y1l süreli etkisini belirlemektir. 


\section{MATERYAL VE METOT}

\section{A. DENEME SAHASININ TANITIMI}

Deneme sahas1 (Y:476652 X:4504283 800 m) Gölcük Orman İşletme Müdürlüğü, Gölcük Orman İşletme Şefliğinin 40 numaralı bölmesinde yer almaktadır, Kuzey bakıda yer alan deneme sahası yaklaşı \% 25-30 eğime sahiptir. Amenajman planı verilerine göre II. bonitetteki meşcerenin ortalama yaş1 15'dir. Sahadaki hakim tek tür Anadolu kestanesi olmakla birlikte, meşcere altında \% 30-40 örtme derecesindemor çiçekli orman gülüne (RohododendronponticumL.) rastlanmaktadır.

Deneme sahasında kontrol parsellerinin birinde bir adet toprak profili açılarak 0-30, 30-60, 60-90 cm derinlikte toprak örnekleri alınmış ve bazı toprak özellikleri analiz ettirilmiştir. Analiz sonuçlarına göre üst toprak balçık iken 30-60 cm derinlikte killi balçık, $60 \mathrm{~cm}$ derinlikten sonra tekrar balçığa dönüşmektedir. Toprak az taşlı ve geçirgenliği oldukça yüksektir. Toprak reaksiyonu (pH) 4.6-4.9 arasında değiştiğinden bu toprakların asit reaksiyonlu esmer orman toprağı sınıfına girdiği söylenebilir.

Deneme sahasına en yakın meteoroloji istasyonu Gölcük Meteoroloji İstasyonu'dur (DMİ; 40 $71^{\prime} \mathrm{K}$; $29^{\circ} 81^{\prime} \mathrm{D} ; 0.0 \mathrm{~m}$, rasat süresi 1929-2018). İklim verileri deneme sahasına (800m) enterpole edilmesi neticesinde; vejetasyon periyodu Nisan-Ekim ayları arasında gerçekleşmekte ve saha bu dönemde ortalama $504 \mathrm{~mm}$ yağış almaktadır. Deneme sahasının (1929-2018) enterpole edilmiş ortalama sıcaklık ve yağış verilerinden elde edilen Walter iklim diyagramına göre, sahada su noksanı (kurak dönem) bulunmamaktadır.

\section{B. YÖNTEM}

Aralama denemeleri 2017 yılı sonbaharında rastlantı bloklarına göre üç tekrarlı kurulmuş ve dört farklı şiddette (kontrol, mutedil, şiddetli ve çok şiddetli) aralama uygulanmıştır. Müdahale şiddetinin belirlenmesinde göğüs yüzeyi $(\mathrm{GY})$ esas alınmıştır. Deneme sahalarında gögüs yüzeyi'nin $\% 0$ (kontrol), \% 18.2'si (mutedil), \% 34'ü (şiddetli) ve \% 49'u (çok şiddetli) oranında aralamayla meşcereden çıkartılmıştır. Her denemede parsel büyüklüğü 0,09 ha $(30 \times 30 \mathrm{~m})$ alınmış ve işlemler tüm parsele uygulanmıştır. Parsel kenarlardaki $10 \mathrm{~m}$ 'lik şeritler izolasyon amaçlı bırakılarak parselin ortasındaki 0.04 ha alan $(20 \times 20 \mathrm{~m})$ ölçüm amacıyla kullanılmıştır. Blok ve parsellerin meşcere özellikleri bakımından mümkün olduğunca homojen yapıda olmasına dikkat edilmiştir. Blokların ve parsellerin araziye aplikasyon edilmesinde şerit metre, eğimölçer ve pusula kullanılmıştır. Aralama uygulanan parsellerde istikbal vaat eden ağaca baskı yapan gövdeler, sıkışık gövdeler, çatal gövdeler ve kırbaçlayıcılar ile ara ve alt tabakadaki ölmüş veya hastalıklı bireyler aralama şiddetine göre parselden çıkartılmıştır. Kontrol parsellerinde de tüm ağaçlar korunarak, hiçbir müdahale uygulanmamıştır. Aralama müdahaleleri uygulandıktan sonra kalan ağaçların numaralarını belirginleştirmek için yağlı boya ile tekrardan yazılmış ve gögüs yükseklikleri işaretlenmiştir. Parsellerde kesilen ağaçların dip kütüklerinde yapılan yaş halkası sayımlarıyla meşcere yaşları tam olarak belirlenmiştir.

Deneme sahalarında $4 \mathrm{~cm}$ ve üzerindeki ağaçların göğüs çaplarının ilk ölçümleri 2017 yılı sonbahar mevsiminde yapılmıştır. Son ölçümler ise numaralı ağaçlarda 2018 yılı Kasım ayında tekrar yapılmıştır. Ağaçların çap ölçümleri kumpas uçları her zaman aynı yöne (eğim aşağı) bakacak şekilde ve $0,1 \mathrm{~cm}$ hassasiyetinde gerçekleştirilmiştir. Deneme sahalarında, her bir parselde ağaçların çap değerleri toplamının aritmetik ortalaması alınarak, parsellerin ortalama çapı bulunmuştur. Her parselde, ağaçların araştırma periyodu sonunda ölçülen çap değerlerinden başlangıçtaki çap değerleri çıkarılarak çap artımı hesaplanmıştır. Aralama öncesi başlangıç çap değerleri $4 \mathrm{~cm}$ 'lik çap sınıflarına (4,0-7,9 cm; 8,0-11,9 cm; 12,0-15,9 cm; 16,0-19,9 cm; 20,0-23,9 cm; 24,0-27,9 cm; 28,0-31,9 cm) ayrılmıştır. Her bir çap sınıfının çap artımını belirlemek için periyot sonu çap değerlerini belirlemek için 2018 yılı çap değerlerinden 2017 yılı çap değerleri çıkarılmıştır. Böylece ortalama çap artımlar 
parseldeki tüm ağaçları kapsayacak şekilde parsel bazında (meşcere düzeyinde) ve çap sınıfları bazında ayrı ayrı hesaplanmıştır.

Ölçülen çap değerlerinden her parselde ağaçların 2017 y1lı ve 2018 y1lı göğüs yüzeyleri hesaplanmıştır. Ağaçların gögüs yüzeyleri toplanarak, hektara çevirme katsayısıyla çarpılmak suretiyle hektardaki değeri $\left(\mathrm{m}^{2} \mathrm{ha}^{-1}\right)$ bulunmuştur. 2018 y1lı göğüs yüzeyi değerlerinden 2017 y1lı göğüs yüzeyi değerleri çıkarılarak her parselin göğüs yüzeyi artımları $\left(\mathrm{m}^{2} \mathrm{ha}^{-1}\right)$ belirlenmiştir.

Ağaçların gövde hacminin belirlenmesinde aynı yörede Seçgin and Özbayram [16]'in elde ettiği çapa bağlı hacim denklemi kullanılmıştır (Denklem 1).

$$
V=0.0004 d^{2}+0.0005 d-0.0028
$$

Denklemde V gövde hacmini $\left(\mathrm{m}^{3}\right)$, $d$ ise göğ̈̈s çapını $(\mathrm{cm})$ belirtmektedir.

Parsellerdeki tüm ağaçların hacimleri toplamı hektara çevrilerek meşcere hacmi $\left(\mathrm{m}^{3} \mathrm{ha}^{-1}\right)$ belirlenmiştir. 2018 yılı hacim değerinden 2017 yılı meşcere hacminin farkı alınarak hacim artımı bulunmuştur.

\section{C. İSTATISTIKİ ANALIZ}

Aralama şiddetinin aralama öncesi ve sonrası ağaç sayısı (AS), göğüs çapı, göğüs yüzeyi (GY) ve hacim (V) değerleri ile bunların bir yıllık artımlarına etkisini belirlemek için elde edilen verilere varyans analizleri (ANOVA) uygulanmıştır. Aralama ve başlangıç çap sınıflarının çap artımlarına etkisini belirlemek için iki yönlü varyans analizi (Two-way ANOVA) uygulanmıştır. Bu durumda bloklarda ana parselleri (main-plot) aralama şiddeti, alt parselleri (sub-plot) ise çap sınıflarının oluşturduğu kabul edilmiştir. Varyansanaliz sonuçlarının önemli $(\mathrm{P}<0.05)$ bulunması halinde değişkenlere ait ortalamaların karşılaştırılmasında Duncan testi kullanılmıştır. İstatistik analizler IBMSPSS Ver.22 istatistik paket programında gerçekleştirilmiştir.

\section{BULGULAR VE TARTISYMA}

\section{A. ARALAMA ÖNCESİ MEŞCERE ÖZELLİKLERİ}

Meşcerelerin aralama öncesi çap, meşcere göğüs yüzeyi, meşcere hacmi değerleri işlemlere göre istatistiki olarak benzerdir $(\mathrm{P}>0.05)$. Yani deneme alanı aralama öncesi meşcere özellikleri bakımından homojendir (Tablo 1).

Tablo 1. Kestane baltalı̆̆ında aralama öncesi ağaç saylsı (AS), göğüs çapı, göğüs yüzeyi (GY) ve hacim (V) değerleri

\begin{tabular}{ccccc}
\hline Aralama Şiddeti & $\begin{array}{c}\text { AS } \\
(\text { adet })\end{array}$ & $\begin{array}{c}\text { Çap } \\
(\mathrm{cm})\end{array}$ & $\begin{array}{c}\text { GY } \\
\left(\mathrm{m}^{2} h \mathrm{a}^{-1}\right)\end{array}$ & $\begin{array}{c}\text { V } \\
\left(\mathrm{m}^{3} \mathrm{ha}^{-1}\right)\end{array}$ \\
\hline Kontrol & $5076(477) \mathrm{a}$ & $8.53(0.39) \mathrm{a}$ & $31.99(0.84) \mathrm{a}$ & $170.38(4.37) \mathrm{a}$ \\
Mutedil & $4652(826) \mathrm{a}$ & $8.40(0.51) \mathrm{a}$ & $26.49(2.90) \mathrm{a}$ & $140.90(15.28) \mathrm{a}$ \\
Şiddetli & $4865(317) \mathrm{a}$ & $8.78(0.14) \mathrm{a}$ & $29.83(1.70) \mathrm{a}$ & $159.09(9.19) \mathrm{a}$ \\
Çok Şiddetli & $5150(599) \mathrm{a}$ & $9.20(0.67) \mathrm{a}$ & $34.55(7.10) \mathrm{a}$ & $184.35(38.35) \mathrm{a}$ \\
P-değeri & 0.336 & 0.364 & 0.126 & 0.129 \\
\hline
\end{tabular}

Aralama öncesi ortalama ağaç sayısı, çapı, göğüs yüzeyi ve hacim değeri sırasıyla 4936 adet, $8.73 \mathrm{~cm}$, $30.71 \mathrm{~m}^{2}$ ha $^{-1}$ ve $163.68 \mathrm{~m}^{3} \mathrm{ha}^{-1}$ olarak belirlenmiştir. 


\section{B. ARALAMANIN ÇAP GELISSIMIMINE ETKISİ}

Varyans analizi sonuçlarına göre; aralama sonrası kalan meşcere (2017 yılı) çapı işlemler arasında önemli fark göstermemektedir ( $\mathrm{P}>0.05)$. Ancak, aralama şiddetinin 2018 yllı çap değerine ve çap artımına etkisi önemli bulunmuştur $(\mathrm{P}<0.05)$.

Çap 2017 değeri tüm işlemlerde benzer ve ortalama 8.6 cm'dir. Ancak 2018 yılı çap değeri en yüksek çok şiddetli işlemde iken, diğer işlemlerde benzer bulunmuştur. Çap artımı ise en yüksek çok şiddetli müdahale gören parsellerde iken en düşük çap artımı ise kontrol ve mutedil aralama işlemlerinde meydana gelmiştir (Tablo 2). Diğer bir ifadeyle çok şiddetli aralama parselinde çap artımı kontrole göre \% 100 daha yüksek bulunmuştur.

Tablo 2. Kestane baltallklarında aralama şiddetinin çap gelişimine etkisi

\begin{tabular}{cccc}
\hline Aralama Şiddeti & $\begin{array}{c}\text { Çap 2017 } \\
(\mathrm{cm})\end{array}$ & $\begin{array}{c}\text { Çap 2018 } \\
(\mathrm{cm})\end{array}$ & $\begin{array}{c}\text { Çap Artımı } \\
(\mathrm{cm})\end{array}$ \\
\hline Kontrol & $8.53(0.39) \mathrm{a}$ & $8.73(0.46) \mathrm{a}$ & $0.20(0.06) \mathrm{a}$ \\
Mutedil & $8.18(0.46) \mathrm{a}$ & $8.67(0.59) \mathrm{a}$ & $0.27(0,27) \mathrm{a}$ \\
Şiddetli & $8.53(0.19) \mathrm{a}$ & $9.07(0.12) \mathrm{a}$ & $0.29(0.29) \mathrm{ab}$ \\
Çok Şiddetli & $9.15(0.52) \mathrm{a}$ & $9.99(0.02) \mathrm{b}$ & $0.40(0.40) \mathrm{b}$ \\
P-değeri & 0.050 & 0.012 & 0.036 \\
\hline${ }^{*}$ Her değişken içinde sütunda aynı harfle gösterilen ortalamalar farksızdır $(\mathrm{P}<0.05)$.
\end{tabular}

Çok şiddetli aralanan parsellerin daha fazla çap artımı yapmasının nedeni; aralamayla meşcerede az sayıda kalan ağaçların diğer işlemlere göre daha fazla 1şık, su ve besin maddesinden yararlanmasıyla açıklanabilir. Nitekim Wang, et al. [17] aralamaya tepki olarak artan çap büyümesinin net fotosentez oranı, faydalı su ve azot miktarının artmasıyla yakın ilişkili olduğunu bildirmektedir. Bu sonuçlara benzer bulgular yapraklı ağaç türlerinde yapılmış çalışmalarda [10,11, 18-21] ve bazı ibreli türlerde [22-24] elde edilmiştir.

Aralama şiddeti, çap sınıfları ve aralama şiddeti x çap sınıfı etkileşimin çap artımına etkisi istatistiki olarak önemli bulunmuştur $(\mathrm{P}<0.05)$. Aralama şiddeti çap artımını önemli oranda etkilemiş, ancak bu etki çap sınıfları bazında değişkenlik göstermiştir (Şekil 1).

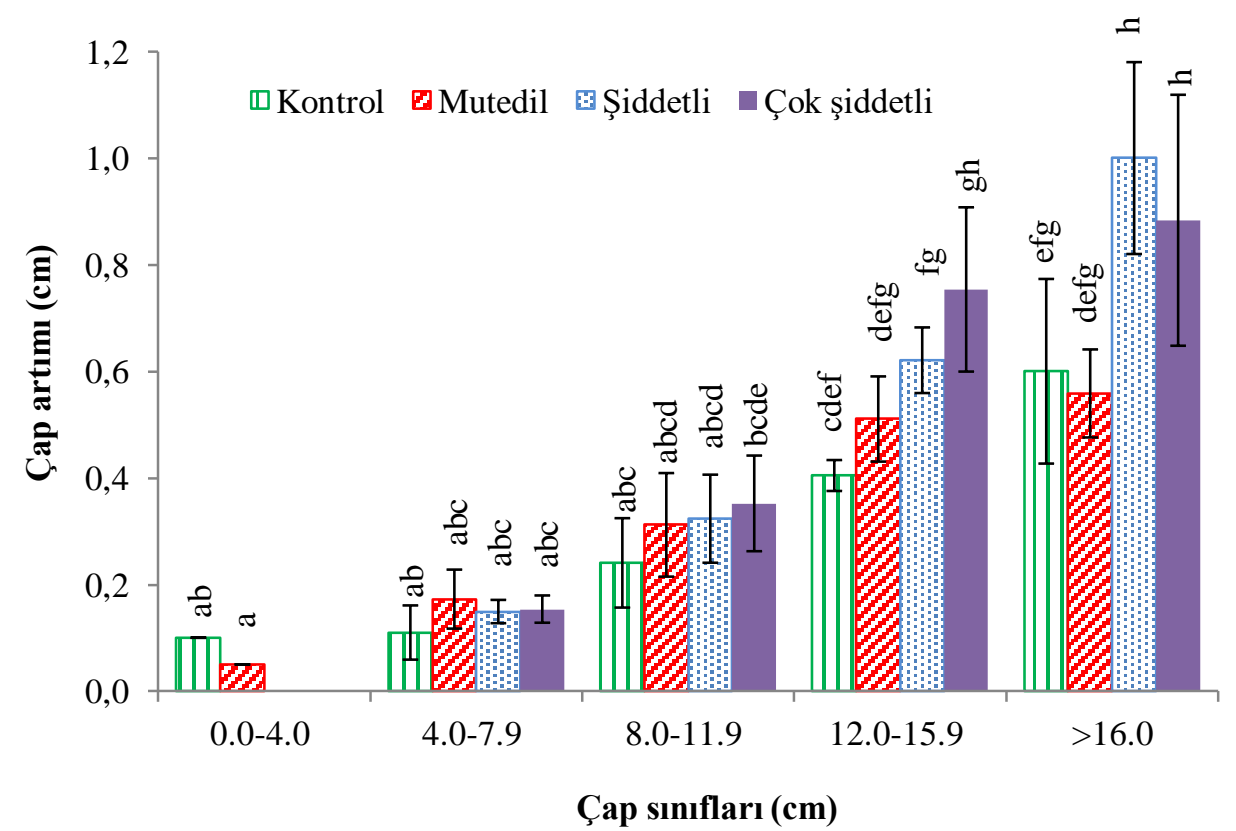

Şekil 1. Aralama şiddetinin başlangıç çap sınıfları bazında çap artımına etkisi 
Aralamadan bir yıl sonraki en büyük çap artımı şiddetli ve çok şiddetli parsellerdeki başlangıç çap değeri $16 \mathrm{~cm}$ den daha kalın ağaçlarda meydana gelmiştir. En yüksek çap artımı yapan bu ağaçlar kontrol parselindeki en ince çap kademesindeki $(0-4 \mathrm{~cm})$ ağaçlardan $0.84 \mathrm{~cm}$ den daha fazla çap kazanımı yapmışlardır. Şiddetli ve çok şiddetli aralanan parseldeki $16 \mathrm{~cm}$ den daha kalın ağaçlar kontroldeki aynı kalınlıktaki ağaçlardan göre \% 47 daha fazla çap artımı yaparken, 16-19.9 cm çap sınıflarındaki şiddetli işlemdeki çap artımı kontrolden $\% 86$ daha fazladır.

Genel olarak çap sınıfı artıkça çap artımı da artmaktadır. Benzer sonuçlar yapraklı türlerde yapılmış çalışmalarda [25-29] bulunmuştur. Bunun nedeni, kalın çaplı ağaçlarının galip tabakada yer almaları, daha iyi tepe geliştirmiş olmaları, daha fazla su ve besin maddesinden faydalanmalarıyla açıklanabilir. Assmann [30] ve Nyland [14]boylu ağaçların daha fazla güneş enerjisi yakaladığını, yüksek düzeyde fotosentez ve büyüme yaptığını belirtmektedir.

\section{ARALAMANIN GÖĞÜS YÜZEYİNE ETKİSI}

Aralama sonrası kalan meşcere (2017 y1lı) göğüs yüzeyi ile 2018 yılı göğüs yüzeyi işlemler arasında farklılık göstermektedir $(\mathrm{P}<0.05)$. Fakat aralamanın göğüs yüzeyi artımına etkisi önemli bulunmamıştır ( $\mathrm{P}>0.05)$. Gögüs yüzeyi 2017 değeri kontrol parseli hariç diğer işlemlerde benzer ve ortalama $20.2 \mathrm{~m}^{2}$ ha $^{-1}$, dir. 2017 gögüs yüzeyi kontrol işleminde diğerlerine göre \%58 daha fazladır (Tablo 3).

Tablo 3. Kestane baltalıklarında aralama şiddetinin göğüs yüzeyi (GY) gelişimine bir yıllık etkisi

\begin{tabular}{cccc}
\hline Aralama Şiddeti & $\begin{array}{c}\text { GY 2017 } \\
\left(m^{2} h a^{-1}\right)\end{array}$ & $\begin{array}{c}\text { GY 2018 } \\
\left(m^{2} h a^{-1}\right)\end{array}$ & $\begin{array}{c}\text { GY Artımı } \\
\left(m^{2} h a^{-1}\right)\end{array}$ \\
\hline Kontrol & $31.99(0.83) \mathrm{b}$ & $33.63(0.81) \mathrm{b}$ & $1.64(0.40) \mathrm{a}$ \\
Mutedil & $21.63(1.74) \mathrm{a}^{*}$ & $23.05(1.76) \mathrm{a}$ & $1.42(0.36) \mathrm{a}$ \\
Şiddetli & $19.72(1.62) \mathrm{a}$ & $21.13(1.48) \mathrm{a}$ & $1.40(0.13) \mathrm{a}$ \\
Çok Şiddetli & $19.28(4.46) \mathrm{a}$ & $21.16(5.13) \mathrm{a}$ & $1.87(0.67) \mathrm{a}$ \\
P-değeri & 0.001 & 0.003 & 0.612 \\
\hline "Her değişken içinde sütunda aynı harfle gösterilen ortalamalar farksızdır $(\mathrm{P}<0.05)$.
\end{tabular}

2018 y1lı göğüs yüzeyi değeri en yüksek kontrol işlemde iken, diğer işlemlerde benzer bulunmuştur. Kontrol parselindeki 2018 yılı göğüs yüzeyi diğer işlemlerden ortalama \% 54 daha yüksek bulunmuştur. Göğüs yüzeyi artımı ise tüm işlemlerde benzerdir $\left(1.59 \mathrm{~m}^{2} \mathrm{ha}^{-1}\right)$. Diğer bir ifadeyle, aralama şiddetinin meşcerenin göğüs yüzeyi artımına etkisi önemsizdir. Benzer sonuçlar yapılan başka çalışmalarda da bulunmuştur [10, 31-33]. Ancak aralanan meşcereler daha düşük gögüs yüzeyi'ne sahip olmalarına rağmen bir yılda kontrol kadar göğüs yüzeyi artımı yapmıştır. Aralama sonrası kalan meşceredeki ağaçlar daha fazla çap yaparak, kontroldeki ağaçların yaptığı göğüs yüzeyi artımını yakalamıştır.

\section{ARALAMANIN MEŞCERE HACMINE ETKİSI}

Aralama sonrası kalan meşcere (2017 y1lı) hacmi ile 2018 yılı hacmi işlemler arasında farklılık göstermektedir $(\mathrm{P}<0.05)$. Fakat aralamanın hacim artımına etkisi önemli bulunmamıştır ( $\mathrm{P}>0.05)$.Hacim 2017 değeri kontrol parseli hariç diğer işlemlerde benzer ve ortalama $107.8 \mathrm{~m}^{3} \mathrm{ha}^{-}$ ${ }^{1}$, dır. Kontrol işleminde 2017 yılı meşcere hacmi diğer işlemlere göre \% 58 daha fazladır. 2018 yılı hacim değeri en yüksek kontrol işlemde iken, diğer işlemlerde benzer bulunmuştur (Tablo 4). 
Tablo 4. Kestane baltalıklarında aralama şiddetinin hacim gelişimine bir yıllık etkisi

\begin{tabular}{cccc}
\hline Aralama Şiddeti & $\begin{array}{c}\text { Hacim 2017 } \\
\left(\mathrm{m}^{3} h \mathrm{a}^{-1}\right)\end{array}$ & $\begin{array}{c}\text { Hacim 2018 } \\
\left(\mathrm{m}^{3} h \mathrm{a}^{-1}\right)\end{array}$ & $\begin{array}{c}\text { Hacim Artımı } \\
\left(\mathrm{m}^{3} h \mathrm{a}^{-1}\right)\end{array}$ \\
\hline Kontrol & $170.38(4.37) \mathrm{b}$ & $179.25(4.34) \mathrm{b}$ & $8.87(2.10) \mathrm{a}$ \\
Mutedil & $115.13(9.08) \mathrm{a}$ & $122.85(9.29) \mathrm{a}$ & $7.72(1.95) \mathrm{a}$ \\
Şiddetli & $105.28(8.65) \mathrm{a}$ & $112.86(7.93) \mathrm{a}$ & $7.58(0.72) \mathrm{a}$ \\
Çok Şiddetli & $103.09(23.88) \mathrm{a}$ & $113.14(27.47) \mathrm{a}$ & $10.05(3.60) \mathrm{a}$ \\
P-değeri & 0.002 & 0.004 & 0.633 \\
\hline
\end{tabular}

Her değişken içinde sütunda aynı harfle gösterilen ortalamalar farksızdır $(\mathrm{P}<0.05)$.

Kontrol parselindeki 2018 y1lı hacim değeri diğer işlemlerden yaklaşık \% 54.1 daha yüksek bulunmuştur. Ancak, hacim artımı ise tüm işlemlerde benzer $\left(8.56 \mathrm{~m}^{3}\right)$ bulunmuştur (Tablo 4). Aralama gören parsellerde kalan meşcere hacimde azalma olmasına rağmen, aralanan parseller kontrol kadar hacim artımı gerçekleştirmiştir. Diğer bir anlatımla, meşcere çap artımı ve ona bağlı olarak meşcere hacmi az sayıda ancak çaplı ağaçlar üzerinde toplanmıştır. Dolayısıyla çap artımının hacim artımına yansıması yüksek olmuştur. Benzer sonuçlar yapraklı ağaç türlerinde yapılan çalışmalarda da bulunmuştur $[11,20,21,34,35]$.

\section{SONUC}

$\mathrm{Bu}$ çalışmada elde edilen bir yıllık sonuçlara göre; aralama şiddeti arttıkça kestane baltalıklarında çap ve çap artımı artış göstermiştir. Çok şiddetli aralanan parsellerde çap artımı kontrolün iki katı kadardır. Ayrıca başlangıç çap sınıfı yükseldikçe çap artımı da artmaktadır. Aralama ile ağaçların önemli bir kısmı çıkartılmasına rağmen (özellikler çok şiddetli aralama parselinde \%49'a varan aralama) aralama yapılan parseller kontrol kadar göğüs yüzeyi ve hacim artımı yapmıştır. Aralamanın büyümeye etkisi bağlamında daha uzun süreli sonuçlara ihtiyaç duyulmakla birlikte, ulaşılan bir yıllık sonuçlara göre benzer özellikteki kestane baltalıklarında çok kuvvetli aralamalar (>\%40) önerilebilir. Böylece göğüs yüzeyi ve hacim artım kaybı yaşamadan çap büyümesi maksimize edilebilir. Daha sağlıklı değerlendirmeler içinaraştırmaya konu deneme takip edilmeli ve elde edilen sonuçlar zaman zaman değerlendirilerek literatüre kazandırılmalıdır. Diğer taraftan kestanenin farklı yetişme ortamlarındaki meşcerelerinde de aralama denemeleri kurularak uzun süreli çalışmalar yürütülebilir. Böylece değerli bir ağaç türümüz olan kestane meşcerelerinin verimli şekilde işletilmesi amaciyla aralamalar konusunda uygulamaya önemli katkı sağlanabilir.

TEȘEKKÜR: Bu çalışma Burak SEÇGIN'in yüksek lisans tezinden üretilmiştir.

\section{KAYNAKLAR}

[1] İ. Turna, F. Atar ve E. Atar, "Odun dış1 orman ürünü olarak kestane (Castanea sativa mill.)'nin Türkiye ormancılığındaki önemi," III. Uluslararası Odun Dışı Orman Ürünleri Sетроzуити, Kahramanmaraş, Türkiye, 2014, ss. 958-967.

[2] İ. Turna, M. G. Sertkaya ve F. Atar, "Kestane dal kanseri ile mücadelenin silvikültürel yönden değerlendirilmesi: Kütahya Simav örneği," Türkiye Ormancıllk Dergisi, c. 18, ss. 187-196, 2017.

[3] F. Saatçioğlu, Silvikültür Tekniği, 2. bask1, İstanbul, Türkiye: İÜ Orman Fakültesi Yayınları, 1979, ss. 441-444.

[4] Anonim, "Gölcük Orman İşletme Müdürlüğü, Gölcük orman işletme şefliği ekositem tabanlı fonksiyonel orman amenajman planı (Plan dönemi 2015-2034)," Yayınlanmadı. 
[5] F. Kapucu, H. Yavuz, A. Gül ve N. Mısır, "Kestane meşçerelerinin hasılatı ve amenajman esasları," TÜBİTAK Togtag/Tarp, Türkiye, Rap. 2229, 2002.

[6] E. Mangil, "Doğu Karadeniz Bölgesinde kestane kanseri etmeni Cryphonectria parasitica'nın vejetatif uyum tipi çeşitliliğinde eşeyli üremenin rolü," Yüksek Lisans tezi, Bitki Koruma Bölümü, Adnan Menderes Üniversitesi, Aydın, Türkiye, 2017.

[7] N. Akgün, "Ordu ilinde üretilen kestane balı, akasya balı, orman gülü balı ve yayla ballarının fiziksel ve kimyasal aktiviteleri ile antioksidan özelliklerinin incelenmesi," Yüksek Lisans tezi, Kimya Bölümü, Ordu Üniversitesi, Ordu, Türkiye, 2017.

[8] B. B. Sökmen ve R. İlgün, "Kestane tohumundan (Castanea sativa) lipaz enziminin saflaştırılması ve kinetik özelliklerinin incelenmesi," Anadolu Çevre ve Hayvancılık Bilimleri Dergisi, c. 3 , ss. $100-105$.

[9] H. Spiecker, "Growth of Norway spruce (Picea abies (L.) Karst.) under changing environmental conditions in Europe," Spruce Monocultures in Central Europe - Problems and Prospects, Joensuu, Finland, 2000, pp. 11-27.

[10] A. K. Özbayram, "Düzce yöresindeki Doğu kayını (Fagus orientalis Lipsky) meşcerelerinde aralama şiddetinin büyümeye etkisi," Doktora tezi, Orman Mühendisliği Bölümü, Düzce Üniversitesi, Düzce, Türkiye, 2014.

[11] A. K. Özbayram and E. Çiçek, "Thinning experiments in narrow-leaved ash (Fraxinus angustifolia Vahl.) plantations: 10-year results," New Forests, vol. 49, pp. 585-598, 2018.

[12] T. Odabaşı, A. Çalışkan, ve H. F. Bozkuş, Orman Bakımı, İstanbul, Türkiye: İ̈̈ Orman Fakültesi, 2004, ss. 44-90.

[13] P. Savill, J. Evans, D. Auclair, and J. Falck, Plantation silviculture in Europe. Oxford, UK: Oxford University Press, 1997, pp. 146-156.

[14] R. D. Nyland, Silviculture: concepts and applications. USA: The McGraw-Hill Companies, USA, 1996, pp. 353.

[15] D. M. Smith, B. C. Larson, M. J. Kelty, and P. M. S. Ashton, The practice of silviculture: Applied forest ecology, 9th ed., New York, USA: Wiley, 1997, pp. 99-129.

[16] B. Seçgin and A. K. Özbayram, "Modeling diameter-height relationship and tree volume of sweet chestnut coppice in Gölcük," in International Symposium on Engineering Natural Sciences and Architecture, Kocaeli, Turkey, 2019, pp. 314-317.

[17] J. R. Wang, S. W. Simard, and J. P. Kimmins, "Physiological responses of paper birch to thinning in British Columbia," Forest Ecology and Management, vol. 73, pp. 177-184, 1995.

[18] B. Umut, M. Düncar ve O. Çelik, "Sırıklık çağındaki kayın (Fagus orientalis Lipsky.) mesceresinin bakımı üzerine araştırmalar," İ̧ Anadolu Ormancılık Araştırma Enstitüsü Teknik Bülten, c. 274 , ss. $1-23,2000$.

[19] A. Tüfekçioğlu, S. Güner, ve F. Tilki, "Thinning effects on production, root biomass and some soil properties in a young oriental beech stand in Artvin, Turkey," Journal of Environmental Biology, vol. 26, ss. 5-91, 2005.

[20] J. S. Meadows and J. Goelz, "Fifth-year response to thinning in a water oak plantation in north Louisiana," Southern Journal of Applied Forestry, vol. 25, pp. 31-39, 2001. 
[21] S. Güner, A. Tüfekçioğlu, and N. Çelik, "Effects of thinning, liming, and nitrogen application on the growth of a young orientalis beech (Fagus orientalis Lipsky) forest stand," Fresenius Environmental Bulletin, vol. 26, pp. 6727-6733, 2017.

[22] B. Ceylan, "Muğla yöresindeki genç kızılçam (Pinus brutia Ten.) meşcerelerinde ilk aralama müdahaleleri üzerine silvikültürel araştırmalar," Ormancılık Araştırma Enstitüsü Yayınları, c. 196, ss. $1-102,1986$.

[23] H. Mäkinen and A. Isomäki, "Thinning intensity and growth of Norway spruce stands in Finland," Forestry, vol. 77, pp. 349-364, 2004.

[24] H. Mäkinen and A. Isomäki, "Thinning intensity and growth of Scots pine stands in Finland," Forest Ecology and Management, vol. 201, pp. 311-325, 2004.

[25] A. K. Özbayram, "Düzce yöresindeki doğu kayını (Fagus orientalis Lipsky) meşcerelerinde aralama şiddetinin büyümeye etkisi," Doktora tezi, Orman Mühendisliği Bölümü, Düzce Üniversitesi, Düzce, Türkiye, 2014.

[26] G. Brown, "Growth responses to thinning in eucalypt regrowth forests," Tasforests Hobart, vol. 9, pp. 105-122, 1997.

[27] J. S. G. Meadows, J.C.G., "Thinning in a 28-year-old water oak plantation in north Louisniana: Seven-year results," in Proceedings of the Tenth Biennial Southern Silvicultural Research Conference, Shreveport, Louisiana, USA, 1999, pp. 98-102.

[28] J. Medhurst, C. Beadle, and W. Neilsen, "Early-age and later-age thinning affects growth, dominance, and intraspecific competition in Eucalyptus nitens plantations," Canadian Journal of Forest Research, vol. 31, pp. 187-197, 2001.

[29] K. Kıran, "Doğu kayını meşcerelerinde aralama şiddetinin meşcere, gelecek ağacı ve çap siniflari bazinda büyümeye etkisi," Yüksek Lisans tezi, Orman Mühendisliği Bölümü, Düzce Üniversitesi, Düzce, Türkiye, 2019.

[30] E. Assmann, Principles of forest yield study: Studies in the Organic Production, Structure, Increment and Yield of Forest Stands, Oxford, UK: Pergamon Press, 1970, pp. 520.

[31] E. Çiçek, F. Yılmaz, A. K. Özbayram, M. Efe, M. Yılmaz, and A. Usta, "Effects of thinning intensity on the growth of narrow-leaved ash (Fraxinus angustifolia subsp. oxycarpa) plantations," Turkish Journal of Agriculture and Forestry, vol. 37, pp. 97-104, 2013.

[32] X. Mayor and F. Rodà, "Growth response of holm oak (Quercus ilex L) to commercial thinning in the Montseny mountains (NE Spain)," Annals of Forest Science, vol. 50, pp. 247-256, 1993.

[33] J. S. Meadows and J. C. G. Goelz, "Thinning in a 28-year-old water oak plantation in north louisniana: seven-year results," vol. 16, pp. 98-102, 1999.

[34] A. Juodvalkis, L. Kairiukstis, and R. Vasiliauskas, "Effects of thinning on growth of six tree species in north-temperate forests of Lithuania," European Journal of Forest Research, vol. 124, pp. 187-192, 2005.

[35] H. Pretzsch, "Stand density and growth of Norway spruce (Picea abies (L.) Karst.) and European beech (Fagus sylvatica L.): evidence from long-term experimental plots," European Journal of Forest Research, vol. 124, pp. 193-205, 2005. 